\title{
THE KEY ROLE OF INTERNAL FINANCING AMONG ENTERPRISES FROM FOOD INDUSTRY - CASE OF POLAND, LATVIA AND LITHUANIA
}

\author{
Magdalena Madra-Sawicka ${ }^{1}$, Dr./ assoc.professor \\ ${ }^{1}$ Warsaw University of Life Sciences - SGGW, Faculty of Economic Sciences
}

\begin{abstract}
The aim of the paper was to identify the internal financing role in case of investment expenditures coverage role. The research sample is constituted from the food industry listed Polish, Latvian and Lithuanian companies. The investigated sample has 348 observations. The research horizon covers the period 2004 to 2016. Food industry due to the high operational risk connected with product price volatility often maintain the conservative strategy of financing. The role of internal capital was varied across studied countries sample. The highest importance in case of financing the investment by internal capital was recorded in Lithuania where the half of those funds were intended for investment in fixed assets issue. In case of economic downturn, the higher share of internal financing was left for the liquidity hedge and the lower investment expenditures were carried. The carried study confirmed the strong manager's preference in term of internal financing sources in case of growth strategy.
\end{abstract}

Key words: internal financing, food industry, Poland, Latvia, Lithuania, stock exchange. JEL code: Q13, Q14

\section{Introduction}

The optimal structure of capital is a compromise between profit and risk acceptance level, which influence the level of debt or demand for external financing. The financing strategy, which aims to minimize the involvement of foreign capital and thus reduce the financial risk, is demonstrating a conservative approach of managers to capital structure decisions. It is reflected by limiting the share of foreign capital share in the capital structure and expansion of the demand for internal financing. A high level of internal financing in a company may lead to a conservative financing strategy and determine the growth rate based mostly on operational efficiency.

Internal financing is one of the results of efficient operating activities of a firm, not its activity on the financial market. The internal sources of financing are defined as the resources of the owner or shareholders of enterprises invested at the time of setting up the business and later reinvested. Thus, the internally generated funds become the primary source of funds that support the increase of the scale and scope of operating activities. Internal financing could be also identified as available cash balance, which may be related to the accumulated savings in the enterprise. Another approach divides internal funding into funds acquired through asset conversion or through capital formation and indicated their impact on working capital (Madra-Sawicka, 2016). Internal financing is often synonymous with the concept of self-financing and means the process of financing from retained earnings, long-term provision, depreciation and from the transformation of possessed assets. The most often used definition of internal financing (also called cash flow) consists of retained earnings and amortization. Therefore, the decision of managers depending on the adopted depreciation methods will condition the internal sources availability in a given period (Circiumaru, Dracea and Stanciu, 2011). As a rule, the amortization capital should be accumulated for the future reconstruction of the fixed assets. However, actual and economic consumption often does not coincide with the period of redemption of the asset book value (Kamoto, 2014). This decision could be diversified across investigated financial markets due to different accounting and tax rules.

The components of internal financing have an impact on the level of the financial result. In profitable enterprises, managers prefer financing through retained earnings, that is why it is expected that relationship between profitability and debt engagement is negative, as evidenced in many studies (Myers and Majluf, 1984; Shun-Yu Chen, 2011). Highly profitable companies will 
reduce external financing due to the ability to cover internal capital needs (Barton, Hill and Sundaram, 1989; Abor, 2007; Bannier and Zahn, 2012). Internal financing among such companies may be used to finance investments and support faster growth (Bottazzi, Secchi and Tamagni, 2014). It confirmed the discussion of Carpenter and Petersen that the external capital is typically more expensive than internal financing (Carpenter and Petersen, 2002). On the other hand, the increased involvement of internal financing contributes to the higher cost of capital, due to the lower efficiency of equity capital engagement.

The excessive preference for internal financing sources may lead to a reduction of the company's growth potential when company noticed a low level of profitability. Lack of diversification of financing sources contributes to the relaxation of investment discipline and strengthens preference to self-sufficiency among managers. Therefore, a high share of internal capital may indicate a greater importance of the company's financial security than the level of profitability. Nevertheless, the inefficient use of internal financing may necessitate the need to increase the involvement of foreign capital (Frielinghaus, Mostert and Firer, 2005).

During the investments process, one of the most important problems is the selection of the capital sources. Determinants that influence the level of internal financing are related to the company's investment cycle, the adopted financing strategy, the level of operating profitability, legal form, financial situation and access to alternative external financing. According to the hierarchy theory when achieved profits are greater than investment needs, managers will pay off liabilities first, and the remaining surpluses invested in liquid, short-term securities (FrancDabrowska, 2006; Bhama, Jain and Yadav, 2015). As a result, internal financing allows to reduce the financial risk, but the available funds may be sufficient for only replacement investments in fixed assets with limited possibility to access the path faster growth. Managers that undertake new investments prefer to finance or co-finance them with funds from retained profits mostly due to the lack of information asymmetry problems (Frank and Goyal, 2003). Accumulated financial capital in the company, in order to fund the resources for development, could reduce this problem temporarily. The asymmetric information problems are the main reasons that explain companies' reliance on internal funds, but they are less severe in case of listed firms (Requejo, 2016). However, the internal and external funds are not perfect substitutes because of transaction costs, tax advantages, agency problems or costs of financial distress (Rahaman, 2011) and internal financing could be unavailable for those firm that characterized with low profitability.

The strong preference of internal capital usage for investments financing do not support striving for an optimal capital structure (Lopez-Gutierrez, Sanfilippo-Azofra and Torre-Olmo, 2015). However, the capital investments of firms' largely depend on internal sources of financing and the ability of companies to internally generate funds for investments (Pavlovic, Bukvic and Gajic, 2016). The determinant of high importance for managers in case of increasing capital expenditures is to preserve the financial flexibility that influences the structure of capital relation in the enterprise. However, the strong preference to maintain the financial surplus result in the reduction of high-value investment expenditures (Bhama, Jain and Yadav, 2015).

The study uses a firm-level panel data set of all publicly traded firms from the food industry on emerging market. The data were collected from consolidated and individual financial statements expressed in mln of U.S. dollars. Data were retrieved from two sources. The primary source was the Emis Intelligence database. Additional items have been collected from Datastream. The investigated period covers 2004-2016. The database has 348 observations of companies from 3 
countries such as Poland (16 companies), Latvia ( 5 companies) and Lithuania ( 6 companies). The lowest number of units in the sample represent period 2004-2006 - 26 companies, the remaining period of research is represented by 27 companies.

The research aim is to examine the determinants and level of accessible internal financing for investment among enterprises in Poland, Latvia, and Lithuania.

The research hypothesis is as follows:

H1: The level of internal financing determines the investment expenditures among food industry companies listed on the stock exchange.

H2: Companies from Poland, Latvia, and Lithuania varied with the internal financing agreement in investments expenditures.

Specific research tasks in the study covers:

- Identification of companies' financial situation in aspect of capital demand,

- Investigation of the internal financing role in the investment process.

In the research different methods were applied. In the theoretical part of the paper, the descriptive method was applied for the introduction. The research part covers the descriptive statistics for investigated variables which play the crucial role in internal financing assessment. The nonparametric Spearman correlation was used to assess the strength and significance of the relation between investigated ratios. The last part of the study covers variation analyses carried out by using the ANOVA Kruskal-Wallis test and the multiple comparisons test. The rank KruskalWallis test ranked together all observations, and the sum of the ranks obtained for each sample separately (Kruskal and Wallis, 1952).

The novelty of the study is a contribution to the existing literature by identifying key determinants of internal financing level used for fixed assets investment coverage in emerging Europe listed companies from the food sector.

\section{Research results and discussion}

\section{Food industry characteristics}

The food sector is one of the most significant sectors of the European economy (Dimara et al., 2008). The role of the food industry is decreasing while the economy develops, but in case of emerging economies, the role of the food industry is much more expressed (Lakner and Popp, 2014). The food sector indirectly affects other domestic sectors included in the value-added chain of the food industry (Buturac, Lovrincevic and Mikulic, 2017).

The food sector companies can apply for dedicated subsidies from EU funds that require own contribution (Ratajczak, 2008) that could consist of internal sources of financing, previously accumulated. A higher level of uncertainty regarding the company's environment determines the shift from the operational investment towards financial investments (Sauner-Leroy, 2004). The level and structure of the capital sources are highly differentiated depending on specific characteristics of activity conducted by the food industry companies listed on the stock exchange (Wasilewski and Zabolotnyy, 2012). Thus, the internal accumulated sources will play a key role in the food industry, especially in case of investments decision and downturn situation on the market.

\section{Financial situation of research firms}

Table 1 presents the financial values and ratios of firms in panel sample and in-country division. The relevant figures clearly indicate that the usage of debt is quite diverse among investigated sector across countries. The average amount of debt ratio in full panel amounts $25.8 \%$, while the 
median level of this ratio was $22.5 \%$. The highest level of the debt was noticed in Lithuanian companies $(30.1 \%)$, while the lowest in Latvian (17.5\%). The external financing was a more crucial source of financing for Lithuanian companies, especially that they noticed the highest share of long-term debt in total debt ratio (LTD \%), that amounts $65.8 \%$. The profitability ratios in research period were quite varied when it comes to average values comparison (minus values for Polish companies - net loss), thus the median level was further discussed. The highest median level of ROA (return on assets) was noticed in Latvian companies (5.7\%), while the lowest in Polish firms (3.9\%). The median level of ROE ratio (return on equity) was the highest in case of Lithuanian companies $(9.8 \%$ ), while the lowest level ratio was noticed among Polish companies (7.5\%). In case of ROS ratio (return on sale), the highest level of this ratio noticed in Latvian sample of firms, which amounts on average $5.4 \%$, while the median value was twice higher $(10.0 \%)$. It supports the conclusion that the highest possibility of generating the internal financing in the research period was achieved by Latvian food industry companies.

The current liquidity ratio in full panel amounts $3.9 \%$, with the median level of $1.5 \%$. The highest current ratio level was the characteristic feature of companies from Latvia, where average amounts $4.9 \%$, and median $2.4 \%$. When it comes to the assessment of this level the value that is over 1.5 could be asses as excess liquidity, but it explains the hedge form operating liabilities. The presented total assets value (TA) and working capital (WC) was used for comparison reason to express the scale of conducted firms' activity. The total average assets value of Polish companies amounts $144.7 \mathrm{mln}$ USD, while the median was twice lower ( $77.5 \mathrm{mln}$ USD). The lowest level of this value noticed Latvian companies, that averaged was $33.8 \mathrm{mln}$ USD and the median level of $6.4 \mathrm{mln}$ USD. However, the lowest value of working capital was among Polish companies ( $5.0 \mathrm{mln}$ USD in average), while the highest in case of Latvian companies. It expresses the conservative manager's attitude to the risk, with the lowest level of all assets was related to the highest level of working capital in Latvian companies.

Table 2 contains descriptive statistics for the full panel and for the subsamples of firms divided into the country stock exchange. The average amount of internal financing to total assets (SF/TA) self-financing measure) for the full panel recorded average level of $-0.5 \%$, and the median was $8.1 \%$. The Lithuanian companies noticed the highest average and median value of this ratio (amounts respectively $9.9 \%$ and $11.8 \%$ ), while the lowest was among Polish firms $(-6.5 \%$, $7.2 \%)$. The Polish companies recorded greater diversity in the distribution of this variable.

In case of Lithuanian companies, the highest share of internal financing to total assets was translated into a higher value of investments expenditure on fixed assets that companies invest during the research period. The relation of this investment to total assets (INV/TA) for these companies recorded average level of $7.1 \%$ and for the median $6.5 \%$. The interesting in the Polish case was that companies noticed a deficit of internal financing in research period. However, they managed to introduce investments on the average level of $6.4 \%$ compared to total assets value ( $4.4 \%$ for median). It supports the conclusion that investments were more often co-financing with external debt or with capital gained from the market. The comparison of the share of investments to self-financing level with the internal financing ratio to total assets it could be concluded that companies from Latvia and Lithuania noticed higher levels of self-financing ratio. It evidenced that the most of the investments in fixed assets in these two countries were supported by a large amount of internal financing. This situation did not appear in case of Polish companies where lack of the most accessible internal financing did not influence on resisting from investment 
expenditures. However, among Polish companies, this situation was quite diverse, thus the median level of internal financing to total assets was higher than an investment to total assets ratio.

Descriptive statistics of the total assets, working capital values and financial ratios for listed firms in 2004-2016, according to country division

\begin{tabular}{|c|c|c|c|c|c|c|}
\hline & $\mathbf{N}$ - valid observations & Mean & Standard deviation & Perc. 10 & Median & Perc. 90 \\
\hline \multicolumn{7}{|c|}{ Latvia } \\
\hline Debt ratio ( $\%$ ) & 65 & 17.5 & 17.0 & 0.0 & 16.2 & 40.4 \\
\hline LTD ( \%) & 41 & 65.8 & 25.3 & 30.1 & 72.9 & 95.3 \\
\hline ROA ( \%) & 65 & 3.1 & 12.6 & -8.6 & 5.7 & 12.3 \\
\hline ROE ( \%) & 65 & 36.6 & 301.7 & -14.7 & 8.7 & 17.0 \\
\hline ROS ( \%) & 65 & 5.4 & 18.9 & -10.4 & 10.0 & 19.4 \\
\hline Liquidity & 65 & 4.9 & 4.4 & 1.2 & 2.4 & 11.3 \\
\hline TA (mIn USD) & 65 & 33.8 & 57.5 & 1.7 & 6.4 & 152.7 \\
\hline WC (mIn USD) & 65 & 6.9 & 12.8 & 0.6 & 1.3 & 35.6 \\
\hline \multicolumn{7}{|c|}{ Lithuania } \\
\hline Debt ratio ( \%) & 78 & 30.6 & 15.2 & 11.0 & 33.0 & 51.2 \\
\hline LTD ( \%) & 77 & 46.6 & 31.9 & 0.0 & 53.3 & 83.6 \\
\hline ROA ( \%) & 78 & 3.4 & 6.1 & -5.3 & 4.9 & 9.7 \\
\hline ROE ( \%) & 78 & 4.6 & 18.5 & -18.4 & 9.8 & 19.7 \\
\hline ROS ( \%) & 78 & 3.0 & 4.6 & -3.8 & 4.2 & 7.5 \\
\hline Liquidity & 78 & 1.5 & 0.8 & 0.6 & 1.3 & 2.7 \\
\hline TA (mIn USD) & 78 & 73.7 & 51.3 & 15.4 & 67.3 & 149.7 \\
\hline WC (mIn USD) & 78 & 12.5 & 19.6 & -4.6 & 4.2 & 40.1 \\
\hline \multicolumn{7}{|c|}{ Poland } \\
\hline Debt ratio ( $\%$ ) & 205 & 26.5 & 81.0 & 0.3 & 21.4 & 38.4 \\
\hline LTD ( \%) & 189 & 37.2 & 30.3 & 0.0 & 37.2 & 77.8 \\
\hline ROA ( \%) & 205 & -10.8 & 104.2 & -16.7 & 3.9 & 14.0 \\
\hline ROE ( \%) & 205 & -25.5 & 265.6 & -29.8 & 7.5 & 29.0 \\
\hline ROS ( \%) & 197 & -39.9 & 253.7 & -7.0 & 4.5 & 13.3 \\
\hline Liquidity & 205 & 4.5 & 22.5 & 0.9 & 1.4 & 3.1 \\
\hline TA (mIn USD) & 205 & 144.7 & 194.4 & 7.3 & 77.5 & 374.5 \\
\hline WC (mIn USD) & 205 & 5.0 & 46.0 & -6.5 & 6.0 & 34.1 \\
\hline \multicolumn{7}{|c|}{ Total sample } \\
\hline Debt ratio ( $\%$ ) & 348 & 25.8 & 63.1 & 0.0 & 22.5 & 41.6 \\
\hline LTD ( \%) & 307 & 43.4 & 31.5 & 0.0 & 44.0 & 83.8 \\
\hline ROA ( \%) & 348 & -5.0 & 80.4 & -10.5 & 4.4 & 13.1 \\
\hline ROE ( \%) & 348 & -7.2 & 242.7 & -22.7 & 8.3 & 23.9 \\
\hline ROS ( \%) & 340 & -21.4 & 194.3 & -5.8 & 4.8 & 13.9 \\
\hline Liquidity & 348 & 3.9 & 17.4 & 0.8 & 1.5 & 5.0 \\
\hline TA (mIn USD) & 348 & 108.1 & 159.7 & 2.3 & 53.3 & 253.9 \\
\hline WC (mIn USD) & 348 & 7.0 & 37.0 & -4.2 & 3.5 & 35.2 \\
\hline
\end{tabular}

Source: author's calculations based on Emis Intelligence and Datastream 
Descriptive statistics of the internal financing and investments expenditures ratios for listed firms in 2004-2016, according to country division

\begin{tabular}{|c|c|c|c|c|c|c|}
\hline & $\mathbf{N}$ - valid observations & Mean & Standard deviation & Perc. 10 & Median & Perc. 90 \\
\hline \multicolumn{7}{|c|}{ Latvia } \\
\hline SF/TA ( \%) & 65 & 6.0 & 12.9 & -7.2 & 8.1 & 16.2 \\
\hline INV/TA ( \%) & 65 & 4.4 & 6.6 & 0.3 & 1.8 & 10.2 \\
\hline INV/SF & 65 & 0.4 & 1.2 & 0.0 & 0.2 & 0.8 \\
\hline \multicolumn{7}{|c|}{ Lithuania } \\
\hline SF/TA ( \%) & 78 & 9.9 & 7.9 & -3.8 & 11.8 & 18.3 \\
\hline INV/TA ( \%) & 78 & 7.1 & 5.6 & 0.9 & 6.5 & 12.3 \\
\hline INV/SF & 78 & 0.8 & 1.6 & 0.0 & 0.5 & 1.4 \\
\hline \multicolumn{7}{|c|}{ Poland } \\
\hline SF/TA ( \%) & 204 & -6.5 & 104.6 & -11.5 & 7.2 & 19.7 \\
\hline INV/TA ( \%) & 191 & 6.4 & 6.7 & 1.1 & 4.4 & 12.6 \\
\hline INV/SF & 204 & 0.6 & 2.2 & 0.0 & 0.4 & 1.5 \\
\hline \multicolumn{7}{|c|}{ Total sample } \\
\hline SF/TA ( \%) & 347 & -0.5 & 80.7 & -5.6 & 8.1 & 18.3 \\
\hline INV/TA ( \%) & 334 & 6.2 & 6.5 & 0.6 & 4.3 & 12.4 \\
\hline INV/SF & 347 & 0.6 & 1.9 & 0.0 & 0.4 & 1.4 \\
\hline
\end{tabular}

Source: author's calculations based on Emis Intelligence and Datastream

The ratios from table 2 for Latvia sample shows that median value of the investment to total assets was relatively low and amount $1.8 \%$ while the self-financing sources noticed the level of $8.1 \%$. This could be concluded by the last ratio that presents the investment value to internal financing level (INV/SF). The lower ratio value than 1.0 than it could be stated the higher usage of internal financing is covering the investment expenses. In case of median values, this ratio was the lowest in Latvian companies (0.2) which could be explained by prudent approach for external capital usage. The Lithuanian companies recorded the highest debt ratio and the ratio of internal financing to assets. The surplus of internal capital is not distributed for investment purposed but it is used for building the financial security of the company. This strategy did not really strictly affect the profitability level of this companies, thus the median-value of ROA, ROE, and ROS was the highest among Lithuanian research countries.

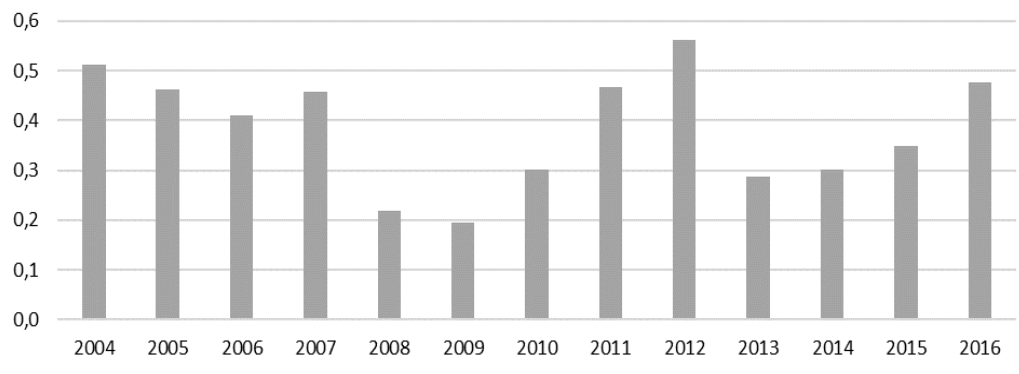

Source: author's calculations based on Emis Intelligence and Datastream

Fig. 1. Relation of investment expenditures on fixed assets to self-financing value in 2004-2016

The Fig. 1 shows the importance of internal financing change in research period. The lowest level of investments to self-financing was noticed in 2008-2009 when the consequences of global financial crisis influence the emerging economies financial markets. During this period the investment expenditures on fixed assets amounts near 20-22 \% of all accessible in current year internal financing sources $(0.20-0.22)$. It supports the statement that in case of economic 
downturn, the higher share of internal financing was left for the liquidity hedge and the smaller investment expenditures were incurred. The highest level of internal financing to investment expenditures value was noticed in 2012 (0.56).

Correlation matrix

\begin{tabular}{|c|c|c|c|c|c|c|c|c|}
\hline SF/TA & 1.0000 & & & & & & & \\
\hline INV/TA & $0.3146 *$ & 1.0000 & & & & & & \\
\hline INV/SF & $0.2086 *$ & $0.6630 *$ & 1.0000 & & & & & \\
\hline TA & $0.2217^{*}$ & 0.0981 & $0.1986 *$ & 1.0000 & & & & \\
\hline LTD & 0.0058 & $0.1845^{*}$ & $0.2444 *$ & $0.4339 *$ & 1.0000 & & & \\
\hline DEBT & 0.0174 & 0.0613 & $0.1863 *$ & $0.7866 *$ & $0.7197 *$ & 1.0000 & & \\
\hline WC & $0.1880 *$ & -0.0655 & 0.0811 & $0.3517 *$ & -0.0805 & 0.0613 & 1.0000 & \\
\hline \multirow[t]{2}{*}{ ROS } & $0.6730 *$ & $0.1996 *$ & $0.1742 *$ & 0.0821 & -0.0538 & -0.0766 & $0.1279 *$ & 1.0000 \\
\hline & SF/TA & INV/TA & INV/SF & TA & LTD & DEBT & WC & ROS \\
\hline
\end{tabular}

$* p$-value $<0,05$

Source: author's calculations based on Emis Intelligence and Datastream

The summary statistics of internal financing and investment ratio variable as well as the basics values and ratios for firms' financial conditions was present in a correlation matrix for the 20042016 period (table 3). It can be seen that most cross-correlation are fairly small. The highest and significant correlation index was noticed between internal financing to total assets ratio and return on sale (ROS) (0.6730). The lower ROS level due to rising raw materials and labour costs or due to increasing competition, effects on the firms' ability to generate internal funds. It also confirmed that operational activity of food industry companies generates the highest amount of internal sources. It is a consequence of a relatively low debt level in case of listed companies in the research industry. The correction index of long-term debt share and debt ratio amounts (0.7197). The significance of these capital structure factors can provide useful hints to the drivers of the observed relation between the debt relation, thus if the debt growth it was a result of higher longterm debt engagement. The cross-correlation between internal financing ratio and investments ratio express that the decision to carry out the investment depends on the internal sources of financing obtained from each assets unit (0.3146). Also, the growth of working capital presents the scale of support the availability of internal financing in firms but is mostly connected with a higher scale of companies' activity.

The Kruskal-Wallis test was conducted on the country differences. It was found to be significant at greater than the 0.01 level in case of three tested variables: SF/TA, INV/TA, and INV/SF. Thus, there appears to be a very definite relationship between country food sector analyses in case of internal financing source and investment expenditures level. The obtained difference in that range could be a result of a different size of this company listed on the capital market in case of investigated sample. Table 4 shows the results of this analysis. The significant differences among all countries were noticed in case of INV/TA ratio, while the SF/TA was significantly differing between Polish and Latvian companies. 
ANOVA Kruskal-Wallis test and the multiple comparisons test results, differences between countries

\begin{tabular}{|l|l|l|l|l|}
\hline & \multicolumn{1}{|c|}{$\begin{array}{c}\text { Kruskala-Wallisa } \\
\text { test }\end{array}$} & $\begin{array}{c}\text { p- } \\
\text { value } \\
\text { for } \mathbf{H} \\
\text { test }\end{array}$ & $\begin{array}{c}\text { Median test } \\
\mathbf{C h i \wedge 2}\end{array}$ & $\begin{array}{c}\text { The result of the multiple } \\
\text { comparisons (based on "z" test and } \\
\text { p-value) }\end{array}$ \\
\hline $\begin{array}{l}\text { SF/TA } \\
(\mathbf{\%})\end{array}$ & $\begin{array}{l}\mathrm{H}(2, \mathrm{~N}=347) \\
=9.4418\end{array}$ & 0.0089 & $\begin{array}{l}10.7109, \mathrm{df}=2 \\
\mathrm{p}=0.0047\end{array}$ & $\begin{array}{l}\text { Statistical important difference between } \\
\text { Latvia and Poland }\end{array}$ \\
\hline $\begin{array}{l}\mathbf{I N V} / \mathrm{TA} \\
(\mathbf{\%})\end{array}$ & $\begin{array}{l}\mathrm{H}(2, \mathrm{~N}=334) \\
=20.8773\end{array}$ & 00000 & $\begin{array}{l}13.3138, \mathrm{df}=2 \\
\mathrm{p}=0.0013\end{array}$ & $\begin{array}{l}\text { Significant differences among all } \\
\text { countries }\end{array}$ \\
\hline INV/SF & $\begin{array}{l}\mathrm{H}(2, \mathrm{~N}=347) \\
=10.1344\end{array}$ & 0,0063 & $\begin{array}{l}12.1646, \mathrm{df}=2 \\
\mathrm{p}=0.0023\end{array}$ & $\begin{array}{l}\text { Only insignificant differences between } \\
\text { LT and PL, the remaining countries were } \\
\text { characterized by significant } \\
\text { diversification }\end{array}$ \\
\hline
\end{tabular}

Source: author's calculations based on Emis Intelligence and Datastream

\section{Conclusions, proposals, recommendations}

1) The analysis' results confirmed the importance of internal financing, as it is the most accessible source for firms' investments expenditures. The high preference of internal financing was also confirmed by the low-level of external debt engagement. It supports the theory of managers' capital preferences defined by pecking order theory.

2) The internal sources measures were diverse between countries group. The lowest level of internal financing was in case of Polish companies while the highest in case of Lithuanian firms. The difference in that filed was shaped by the level of firms' profitability and conservative approach to keep the reserve of internal financing sources that could reduce the level of risk. The Lithuanian firms could follow the pattern of a support of faster growth financed mainly by internal capital. It was possible in case of the high profitability, which supports research results of Bottazai, Secchi, and Tamagni (2014). However, these firms noticed also the highest level of long-term debt, which co-financed the investments in fixed assets compared to other countries groups. Research result support Pavlovic, Bukvic, and Gajic statement that capital investments of firms largely depend on internal sources of financing (2016); however; they need especially in case of listed firms other supplement external sources of capital. The study results confirm the first and second hypothesis.

3) Study contribution builds on a set of contributions to international study for emerging markets, which have tried to evaluate the actual nature of the internal financing determinants among food sector companies. The internal financing measures were proposed by the Author.

4) The empirical examination in this study is limited to few independent variables. The next step of study should base on econometric panel model which will include the main determinants of the internal financing. The further study could include a separate period of global economic crisis when companies decrease sharply the investment expenditures and accumulate the internal capital without investing it. The limitation of a study is not discussed dividend policy of research companies. Thus, companies in emerging market pay dividend rarely, but if the company pay it's often irregularly.

\section{Bibliography}

1. Abor, J. (2007). Debt Policy and Performance of SMEs, The Journal of Risk Finance, 8(4), pp. 364-379. doi: $10.1108 / 15265940710777315$.

2. Bannier, C. E., Zahn, S. (2012). Are SMEs large firms in miniature? Evidence from the growth of German SMEs, International Journal of Entrepreneurship and Small Business, 17(2), p. 220. doi: 10.1504/IJESB.2012.048848. 
3. Barton, S. L., Hill, N. C., Sundaram, S. (1989). An empirical test of stakeholder theory predictions of capital structure, Financial Management, 18(1), pp. 36-44.

4. Bhama, V., Jain, P. K., Yadav, S. S. (2015). Does firms' pecking order vary during large deficits and surpluses? An empirical study on Emerging Economies, Procedia Economics and Finance, 30(15), pp. 155163. doi: $10.1016 / S 2212-5671(15) 01279-4$.

5. Bottazzi, G., Secchi, A., Tamagni, F. (2014). Financial constraints and firm dynamics, Small Business Economics, 42(1), pp. 99-116. doi: 10.1007/s11187-012-9465-5.

6. Buturac, G., Lovrincević, Ž., Mikulic, D. (2017). International competitiveness and restructuring of the Croatian food industry, Acta Oeconomica, 67(3), pp. 435-462. doi: 10.1556/032.2017.67.3.7.

7. Carpenter, R. E., Petersen, B. C. (2002). Is the growth of small firms constrained by internal finance?, Review of Economics and Statistics, 84(2), pp. 298-309. doi: 10.1162/003465302317411541.

8. Circiumaru, D., Dracea, R., Stanciu, C. V. (2011). Self-financing capacity Analysis of Romanian Companies. Case Study: the Automotive Industry, Young Economists Journal/Revista Tinerilor Economisti, 9(17), pp. 24-32.

9. Dimara, E., Skuras, D., Tsekouras, K., Tzelepis, D. (2008). Productive efficiency and firm exit in the food sector, Food Policy, 33(2), pp. 185-196. doi: 10.1016/j.foodpol.2007.08.003.

10. Franc-Dabrowska, J. (2006). Does dividend policy follow the capital structure theory?, Managing Global Transitions, 7(4), pp. 367-382.

11. Frank, M. Z., Goyal, V. K. (2003). Testing the pecking order theory of capital structure, Journal of Financial Economics, 67(2), pp. 217-248. doi: 10.1016/S0304-405X(02)00252-0.

12. Frielinghaus, A., Mostert, B., Firer, C. (2005). Capital structure and the firm's life stage, South African Journal of Business Management, 36(4), pp. 9-18.

13. Kamoto, S. (2014). Impacts of internal financing on investment decisions by optimistic and overconfident managers, European Financial Management, 20(1), pp. 107-125. doi: 10.1111/j.1468-036X.2011.00624.x.

14. Kruskal, W. H., Wallis, W. A. (1952). Use of Ranks in One-Criterion Variance Analysis, Journal of the American Statistical Association, 47(260), pp. 583-621. doi: 10.1080/01621459.1952.10483441.

15. Lakner, Z., Popp, J. (2014). Place and role of food industry in modern economies, Acta Alimentaria, 43(1), pp. 85-92. doi: 10.1556/AAlim.43.2014.Suppl.13.

16. Lopez-Gutierrez, C., Sanfilippo-Azofra, S.,Torre-Olmo, B. (2015). Investment decisions of companies in financial distress, BRQ Business Research Quarterly, 18(3), pp. 174-187. doi: 10.1016/j.brq.2014.09.001.

17. Madra-Sawicka, M. (2016). Self-financing in Agriculture Enterprises Performance., Zeszyty Naukowe Uniwersytetu Szczecinskiego Finanse Rynki Finansowe Ubezpieczenia, 4(4), pp. 425-435. doi: 10.18276/frfu.2016.4.82/1-36.

18. Myers, S. C. and Majluf, N. S. (1984). Corporate financing and investment decisions when firms have information that investors do not have, Journal of Financial Economics, 13(2), pp. 187-221. doi: 10.1016/0304-405X(84)90023-0.

19. Pavlovic, R. Z., Bukvic, R. M., Gajic, A. M. (2016). Internal Sources of Financing Companies on the Basis of Static and Dynamic Indicators: Comparative Analysis, Procedia - Social and Behavioral Sciences, 221, pp. 270-277. doi: 10.1016/j.sbspro.2016.05.115.

20. Rahaman, M. M. (2011). Access to financing and firm growth, Journal of Banking and Finance, 35(3), pp. 709-723. doi: 10.1016/j.jbankfin.2010.09.005.

21. Ratajczak, M. (2008). Wykorzystanie srodków z funduszy Unii Europejskiej w dzialalności malych oraz srednich przedsiebiorstw wiejskich z Warmii i Mazur (Use of funds from European Union in the activities of small and medium rural enterprises from Warmia and Mazury), Roczniki Naukowe Stowarzyszenie Ekonomistow Rolnictwa i Agrobiznesu, 13(1), pp. 313-317.

22. Requejo, I. (2016). Do private family firms rely on internal finance to grow, Working Paper, pp. 1-47. Retrived from:

http://www.fmaconferences.org/Lisbon/Papers/Do_private_family_firms_rely_on_internal_finance_to_grow _Full_paper.pdf

23. Sauner-Leroy, J.B. (2004). Managers and productive investment decisions: the impact of uncertainty and risk aversion, Journal of Small Business Management, 42(1), pp. 1-18. doi: 10.1111/j.1540627X.2004.00094.x.

24. Shun-Yu Chen (2011). Capital structure determinants: An empirical study in Taiwan, African Journal of Business Management, 5(27), pp. 10974-10983. doi: 10.5897/AJBM10.1334.

25. Wasilewski, M. and Zabolotnyy, S. (2012). Forming of the asset and capital structure of agribusiness companies in Poland, EKOHOMIKA, 132, pp. 24-28. 